Neo-Confucian Education 


\section{STUDIES ON CHINA}

A series of conference volumes sponsored by the Joint Committee on Chinese Studies of the American Council of Learned Societies and the Social Science Research

Council.

1. Origins of Chinese Givilization edited by David N. Keightley, University of Califormia Press, 1982

2. Popular Chinese Literature and Performing Arts in the

People's Republic of China, 1949-1979 edited by Bonnie S. McDougall, University of California Press, 1984

3. Class and Social Stratification in Post-Revolution China edited by James $L$. Watson, Cambridge University Press, 1984

4. Popular Culture in Late Imperial China edited by David Johnson, Andrew J. Nathan, and Evelyn S. Rawski, University of Califormia Press, 1985

5. Kinship Organization in Late Imperial China, 1000-1940

edited by Patricia Buckley Ebrey and James L. Watson, University of California Press, 1986

6. The Vitality of the Lyric Voice: Shih Poetry from the Late Han to the T'ang edited by Shuen-fu Lin and Stephen Owen, Princeton University Press, 1986

7. Policy Implementation in Post-Mao China edited by David M. Lampton, University of California Press, 1987

8. Death Ritual in Late Imperial and Modern China edited by James L. Watson and Evelyn S. Rawski, University of California Press, 1988

9. Neo-Confucian Education: The Formative Stage edited by Wm. Theodore de Bary and John W. Chaffee, University of California Press, 1989 


\section{Neo-Confucian Education: \\ The Formative Stage}

EDITED BY

Wm. Theodore de Bary

and

John W. Chaffee

CONTRIBUTORS

Bettine Birge - Peter K. Bol • John W. Chaffee •

Wing-tsit Chan - Ron-Guey Chu $\cdot \mathrm{Wm}$. Theodore de Bary

Patricia Ebrey • Robert Hymes - M. Theresa Kelleher •

Thomas H. C. Lee - Brian McKnight - Tu Wei-ming •

Monica Übelhör • Linda Walton • Pei-yi Wu • Chün-fang Yü •

Erik Zürcher

UNIVERSITY OF CALIFORNIA PRESS

Berkeley Los Angeles London 
This volume was sponsored by the Joint Committee on Chinese Studies of the American Council of Learned Societies and the Social Science Research Council, with funds provided by the National Endowment for the Humanities and the Ford Foundation.

\author{
University of California Press \\ Berkeley and Los Angeles, California \\ University of California Press, Ltd. \\ London, England \\ (C) 1989 by
}

The Regents of the University of California

Library of Congress Cataloging-in-Publication Data

Neo-confucian education: the formative stage / edited by Wm. Theodore de Bary and John W. Chaffee; contributors, Bettine Birge ... [et al.].

p. cm. - (Studies on China; 9)

Includes index.

ISBN 0-520-06393-7 (alk. paper)

1. Education-China-History-To 1912. 2. Neo-Confucianism.

3. Chu, Hsi, 1130-1200. I. De Bary, William Theodore, 1918-

II. Chaffee, John W. III. Birge, Bettine. IV. Series.

LAl131.8.N46 1989

$370^{\prime} .951-\mathrm{dc} 19$

88-24952

CIP

Printed in the United States of America

123456789 
This volume is dedicated to Wing-tsit Chan in acknoweledgment of his leadership of the 1982 conference, in tribute to his many distinguished contributions to the study of Chu Hsi and Neo-Confucianism, and in celebration of his eighty-eighth birthday. 
